\title{
Contribution of Greening and High-Albedo Coatings to Improvements in the Thermal Environment in Complex Urban Areas
}

\author{
Bonggeun Song ${ }^{1}$ and Kyunghun Park ${ }^{2}$ \\ ${ }^{1}$ National Institute of Ecology, 1210 Geumgang-ro, Maseo-myeon, Seocheon-gun, Chungcheongnam-do 325-813, Republic of Korea \\ ${ }^{2}$ Changwon National University, 20 Changwondaehak-ro, Uichang-gu, Changwon-si, Gyeongsangnam-do 641-773, Republic of Korea \\ Correspondence should be addressed to Kyunghun Park; landpkh@changwon.ac.kr
}

Received 13 October 2014; Accepted 5 February 2015

Academic Editor: Marialena Nikolopoulou

Copyright (C) 2015 B. Song and K. Park. This is an open access article distributed under the Creative Commons Attribution License, which permits unrestricted use, distribution, and reproduction in any medium, provided the original work is properly cited.

The aim was to identify microclimate characteristics in relation to ground cover in green areas and the reflectivity of building coating materials. Furthermore, microclimate modeling of temperatures was conducted using ENVI-met, to analyze the effects of improved thermal environments based on increased green areas and increased reflectivity of exterior coatings. The accuracy of ENVI-met was validated through comparisons with field temperature measurements. The RMSE deviation of the predicted and actual field temperature values was $3-6^{\circ} \mathrm{C}$; however, the explanatory power was as high as $60 \%$. ENVI-met was performed for commercial and single residential areas that have high densities of artificial cover materials, before and after changes related to development of green areas and to increase in the reflectivity of coating materials. The results indicated that both areas exhibited distinct temperature reductions due to the creation of green spaces. When the reflectivity of the coating material was increased, a temperature increase was observed in all land-use types. Therefore, in order to improve the thermal environment of complex urban areas, it is necessary to improve green-area development and to use high-reflectivity ground and building cover materials, while taking into account the spatial characteristics of land-use types and their surrounding areas.

\section{Introduction}

Urban areas consist of a variety of land covers and geometrical structures of various heights, characteristics that result in a unique climate. The albedo (reflectance) of land cover is mostly determined by its color. This characteristic has a significant impact on the radiation accumulated within the ground surface and thus on the surface temperature as well [1, 2]. Moreover, urban green areas have the function of lowering the surface temperature of surrounding areas and are thus effective in improving the urban thermal environment $[3,4]$. However, because artificial ground covers like asphalt and concrete, which have low reflectivity, are increasing in urban areas while green areas and water surfaces are decreasing, a great deal of heat is constantly accumulating in our cities [5]. For this reason, issues related to urban thermal environments and urban heat-island effect (urban temperatures clearly higher than outskirts) $[6,7]$ are of growing concern. Recently, climate change has caused record-breaking heat waves that have become a serious environmental issue in urban areas all over the world. This in turn has increased interest in spaceenvironment engineering for improving the thermal outdoor comfort of city dwellers and for minimizing the accumulation of heat in artificial structures [8-11].

Many recent studies have revealed that the thermal environment of urban areas can be improved through methods such as developing green areas and greening the roofs of buildings $[3,12-21]$. Other studies have focused on ways to reduce surface and air temperature by increasing the albedo of roof and land covers and at the same time reducing the energy consumption of buildings [22-34]. Studies have also been conducted on how to adjust the dimensions, configurations, and placement of buildings (urban form and design) to improve the thermal environment. This is 


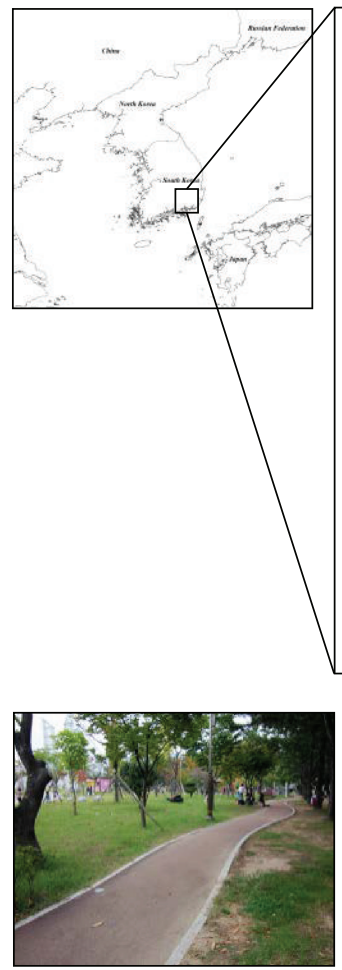

(a)
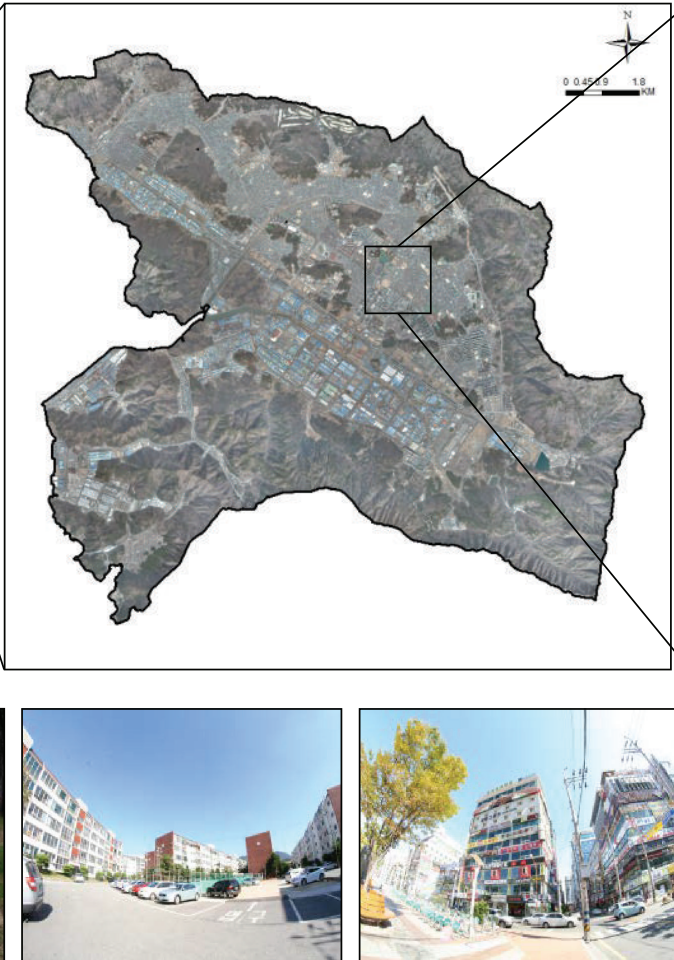

(b)

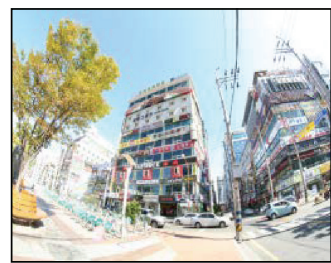

(c)

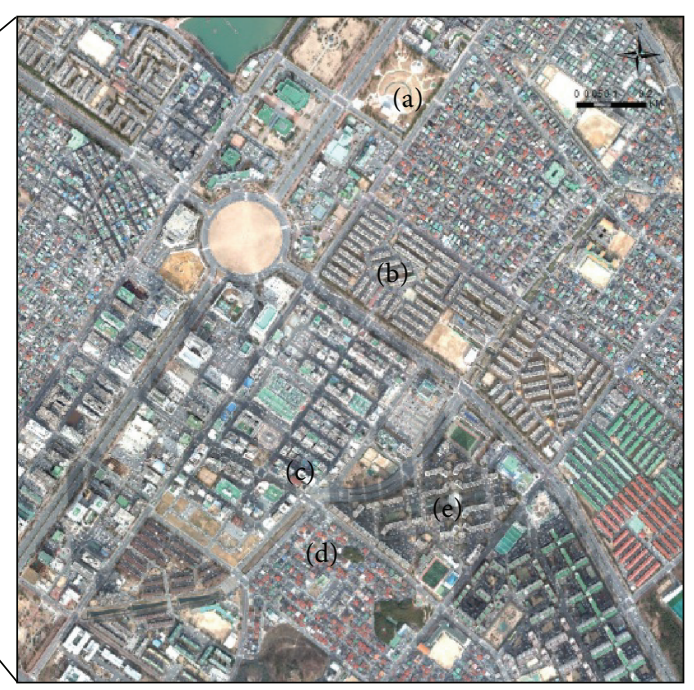

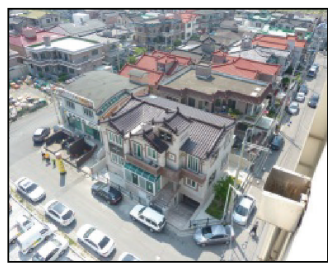

(d)

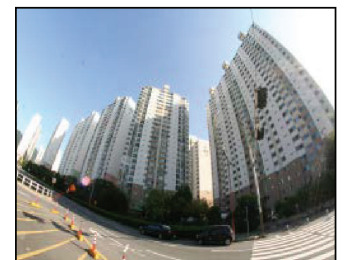

(e)

FIGURE 1: Five analysis areas encompassing different urban landscapes and land-use types in Changwon City, namely, (a) an urban park, (b) a low-rise apartment area, (c) a commercial area, (d) a single residential area, and (e) a high-rise apartment area.

accomplished by making systematic provisions for shade [26, 35-38].

Various studies focused on urban form and design (building dimensions) are being conducted to improve the thermal environment. However, there are too few studies involving complex high-density urban areas. These typically consist of various types of buildings and cover materials, feature extensive land development, and involve complicated landuse types. In recent years, urban areas in South Korea have exhibited increases in power usage and frequent powersupply interruptions, due to a growing number of heat-wave days in summer. These urban areas also face other problems in connection with heat waves, such as increases in disease and death rates [38]. Hence, it is necessary to provide plans for improvement of the outdoor thermal environment that take into account the diverse and complex land-use types, as well as the spatial arrangement, of urban areas in South Korea.

It was the goal of this study to identify microclimate characteristics, in relation to green-area development and the reflectivity of exterior coating materials, using field measurements of temperature in the urban area of Changwon City, South Korea. Furthermore, the effects from improving the thermal environment were identified for various landuse types, and their characteristics were determined. This was accomplished by analyzing the effects from additional green-area development and from the application of highreflectivity cover materials to existing space. For this analysis, the climate model ENVI-met was used. Based on this investigation, a plan for optimal space design to improve the thermal environment was provided at the level of urban environment planning.

\section{Materials and Methods}

2.1. Target Study Area. The urban area of Changwon City $\left(35^{\circ} 14^{\prime} 01.02^{\prime \prime} \mathrm{N}, 128^{\circ} 41^{\prime} 19.95^{\prime \prime} \mathrm{E}\right)$ in South Korea is a basinform city surrounded by mountains, with a population of approximately 50 million [39, 40]. Because it is the first planned city in South Korea, the land-use types there are distinct. These include densely distributed residential, commercial, and public facilities, but large-scale national industrial complexes are also located in the vicinity. The average annual temperature is approximately $15^{\circ} \mathrm{C}$. Warmer weather is experienced in summer, which lasts from June to September (average temperature of $\sim 24^{\circ} \mathrm{C}$ ) [41].

Five different urban land-use types in Changwon City were selected as targets for analysis. These include urban park, low-rise apartment, commercial, single-detached residential, and high-rise apartment areas (Figure 1). The urban park area consists mostly of trees and grass, as well as landscape arrangements such as marble stones and sculpture. The area surrounding the urban park consists of roads, public offices, and single residential areas. The low-rise apartment area consists of relatively low-rise buildings (up to five floors), and the buildings are densely distributed. The land surface in this area is mostly covered with asphalt. Trees are present in 
TABLE 1: Characteristics of land cover at the measure points.

\begin{tabular}{ll}
\hline Site & Land cover \\
\hline & $(1)$ Granite \\
& $(2)$ Brick \\
& $(3)$ Brick \\
Urban park & $(4)$ Lawn \\
(9 points) & $(5)$ Urethane \\
& $(6)$ Wooden board \\
& $(7)$ Brick \\
& $(8)$ Granite \\
& $(9)$ Lawn \\
\hline Low-rise APT & $(10)$ Asphalt \\
(6 points) & $(11)$ Sand \\
& $(12)$ Asphalt \\
Hingle residential & $(13)$ Asphalt \\
(4 points) & $(14)$ Concrete \\
& $(15)$ Asphalt \\
\hline Commercial area & $(16)$ Asphalt \\
(3 points) & $(17)$ Brick \\
\hline & $(18)$ Gravel \\
\hline & $(19)$ Asphalt \\
& $(20)$ Asphalt \\
& $(21)$ Gravel \\
& $(22)$ Asphalt \\
\hline & $(23)$ Sand \\
& $(24)$ Brick \\
& $(25)$ Brick \\
& $(26)$ Tile \\
& $(27)$ Brick \\
\hline & \\
& \\
& \\
&
\end{tabular}

the spaces between the edges of the apartment complex and the buildings. The commercial area consists of very densely distributed high-rise buildings (height $>30 \mathrm{~m}$ ) that are all $10 \mathrm{~m}$ wide. The ground is covered with asphalt. Moreover, the commercial area includes resting places for citizens in the form of a fountain square and a small green park. The single residential area consists of buildings with two floors. The buildings are densely distributed and form a block of approximately 10 houses. The interval between the blocks is approximately $5 \mathrm{~m}$, and the land surface is covered with asphalt. Retail shops ( $20 \mathrm{~m}$ in width) and parking lots covered by asphalt are situated in the area. The high-rise apartment area comprises vast areas of greenery with a spacious square covered in tiles; the building density in this area is not high.

2.2. Field Measurements. Field measurements were conducted in summer between June and August, under clear weather conditions (almost no clouds, less than 10\% coverage). Daytime measurements were conducted on 29 June 2013 and 09 August 2013, whereas nighttime measurements were conducted over three days starting from 14 August 2013. Daytime measurements were conducted from 1:00 p.m. to $3: 30$ p.m. (UTC+9), whereas nighttime measurements were conducted from midnight to 2:30 a.m. (UTC+9), and each round of measurements took approximately $2.5 \mathrm{~h}$. These measurement intervals should have captured the maximum and minimum daily temperatures. As shown in Figure 2 and Table 1, 27 points (urban park: 9, low-rise apartment area: 6, commercial area: 3 , single residential area: 4 , and high-rise apartment area: 5) were selected as the measurement points based on the three-dimensional (3D) spatial characteristics of the buildings and the reflectivity of the ground and building cover materials. The temperatures of bricks, lawn, and granite were measured in the urban park. Most of the temperatures measured in the low-rise apartment, commercial, and single residential areas were for asphalt and concrete. The temperatures measured in the high-rise apartment area were mostly for bricks. The distance from the urban park to the high-rise apartment area is approximately $5 \mathrm{~km}$.

At each study site, three researchers used a mobile meteorological measuring device (Davis Vantage Pro2, accuracy of $\pm 0.5^{\circ} \mathrm{C}$ ) set at a height of $1.2 \mathrm{~m}$ (see Figure 3). The measurements were then taken by fixing the device in a horizontal position, relative to the ground surface, for $2 \mathrm{~min}$. Measurement start and end times, as well as the surface temperatures at each measurement point, were recorded in a field book. Each cycle of measurements occurred in the following order: urban park area $\rightarrow$ low-rise apartment area $\rightarrow$ high-rise commercial area $\rightarrow$ single residential area $\rightarrow$ high-rise apartment area. In the urban park area, the granite material located in the northern section was selected as the measurement point. Since temperature changes as time passes, corrections must be made based on specific time. This study corrected the time to $2 \mathrm{p} . \mathrm{m}$. for daytime measurement and $1 \mathrm{a} . \mathrm{m}$. for nighttime measurement and set the final point of measurement to be equal to the starting point, correcting it through

$$
\begin{gathered}
\alpha=\frac{\left\{\left(X_{f}-X_{s}\right) / X_{f}\right\}}{\left(T_{f}-T_{s}\right)}, \\
Y=X-X \times\left(T-T_{s}\right) \times \alpha .
\end{gathered}
$$

For (1), $X_{f}$ is the measurement value of the end point, $X_{s}$ is the measurement value of the start point, $T_{f}$ is the measurement time of the end point, $T_{s}$ is the measurement time of the start point, $\alpha$ is the correction factor, $X$ is the measured value, $T$ is the measured time, and $Y$ is the corrected value.

2.3. ENVI-Met Model. In this study, thermal-improvement effects were compared by considering outdoor space design using the ENVI-met model version 3.1. This is a microclimate analysis program that simulates meteorological factors (e.g., distribution of air currents, flow fields of fluids, temperature, humidity, and radiation energy) in 3D, based on input information that includes land surface, structures, and vegetation of urban spaces in grid form $[21,42]$. This program has a spatial resolution of $0.5-10 \mathrm{~m}$, temporal resolution of $10 \mathrm{~s}$, and can simulate time frames of $24-48 \mathrm{~h}[18,43]$. 


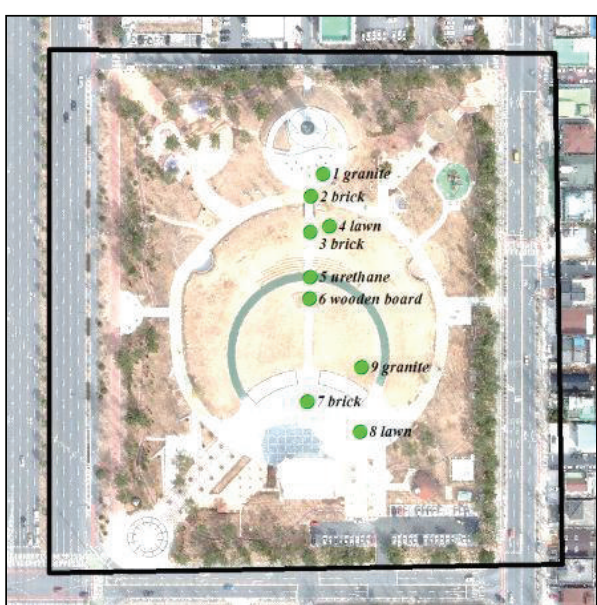

(a)

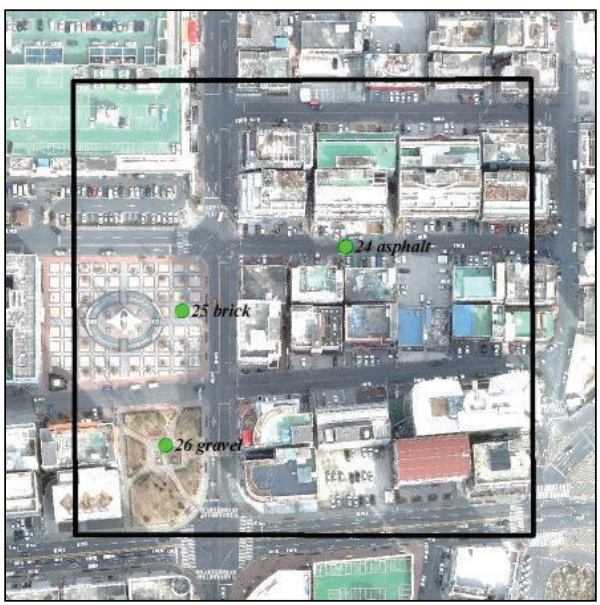

(c)

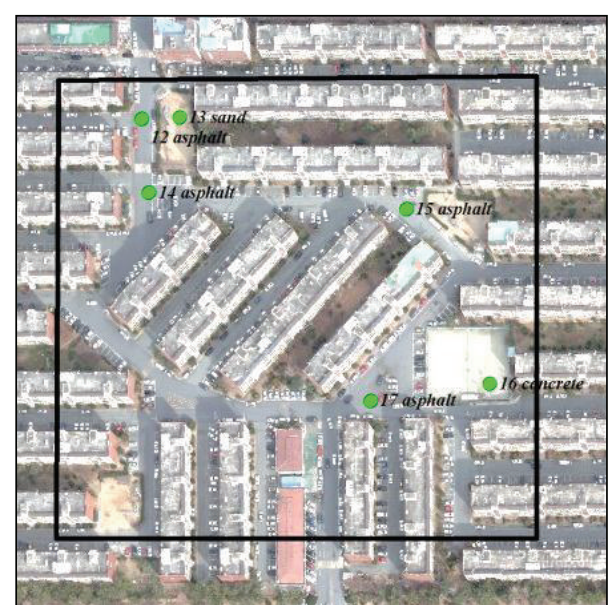

(b)

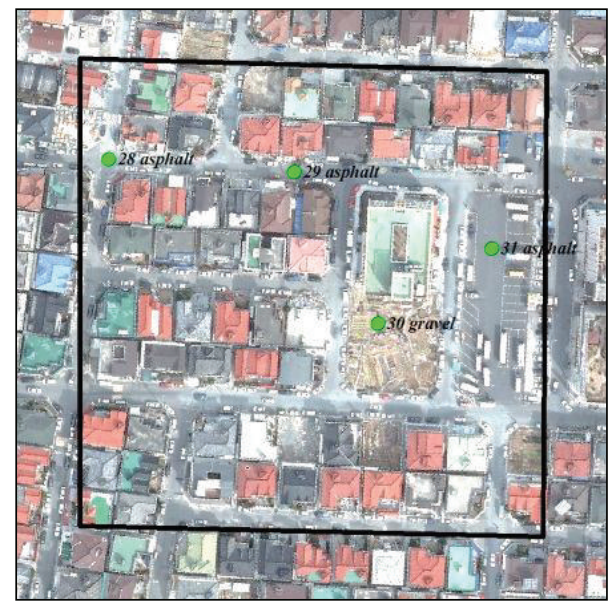

(d)

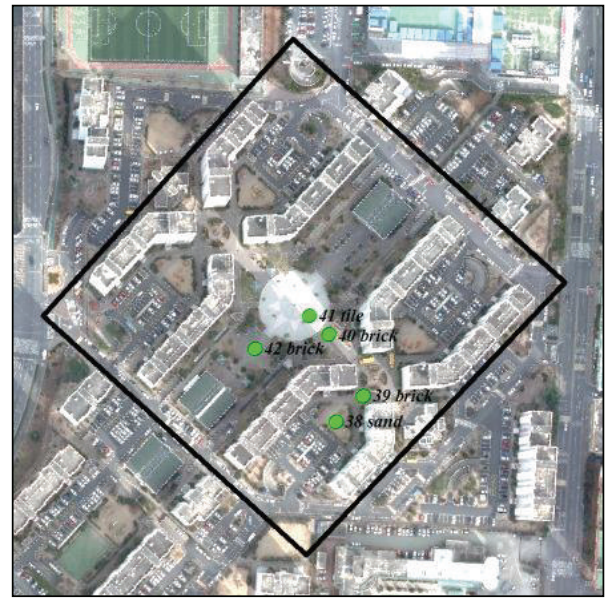

N

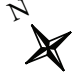

Analysis target area

(e)

Figure 2: Field measurement points in the analysis target sites: (a) urban park area (9 points), (b) low-rise apartment area (6 points), (c) high-rise commercial area (3 points), (d) single residential area (4 points), and (e) high-rise apartment area (5 points). 


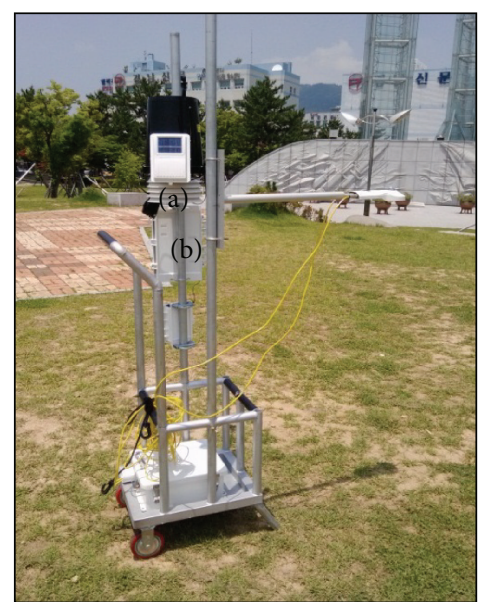

Figure 3: Portable measurement equipment: (a) meteorological measuring device, (b) data logger box.

For this work, the input data consisted of an area input file $(*$. in) and a configuration file (*.cf). The former included representations of the geographic location, building arrangement and height, type of ground cover, or type of vegetation of the target area, whereas, the latter includes the initial simulation of weather conditions. The information for each area input file was compiled based on surface fabric classification, geographic information systems (GIS) data, emissivity and reflectivity of coating materials, and a field survey based on the study by Song [44]. The horizontal grid resolution was set at $4 \mathrm{~m}$ after considering the area of each site, and the vertical grid resolution was set at $1 \mathrm{~m}$. The number of grids was $60 \times 60 \times 30$ grids for the urban park area, $52 \times 52 \times 30$ grids for the low-rise apartment area, $50 \times 50 \times 30$ grids for the high-rise commercial area, 34 $\times 34 \times 30$ grids for the single residential area, and $52 \times$ $52 \times 30$ grids for the high-rise apartment area. Moreover, buildings were rotated vertically or horizontally to accurately express the building shape. The rotation degree was set at $35^{\circ}$ for the urban park area, low-rise apartment area, high-rise commercial area, and single residential area but set at $78^{\circ}$ for high-rise apartment area. A receptor was positioned at the same location as the field measurement point.

The data for factors such as temperature, wind speed, wind direction, and humidity were obtained from an automatic weather-measuring device, which managed the information on weather conditions from the configuration file. This device was installed at the Changwon Disaster Prevention and Countermeasures Headquarters, located near the target area. $\mathrm{Ng}$ et al. [18] stated that the best time to start a simulation is at sunrise and that the total running time should be longer than $6 \mathrm{~h}$, in order to overcome the influence of the initialization. The simulation start time in this study was 06:00 on 29 June, 09 August, and 13 August 2013. The simulation duration was set to $24 \mathrm{~h}$, and the data was stored at $10 \mathrm{~min}$ intervals. Moreover, the albedo of walls was set to 0.2 , and the albedo of roofs was set to 0.3 (Table 2).

For ENVI-met, analysis data was assumed to be measured from a height of $2 \mathrm{~m}$ and at 2 p.m. (daytime) or 1 a.m.
TABLE 2: ENVI-met model configuration-file settings.

\begin{tabular}{lccc}
\hline Category & \multicolumn{3}{c}{ Test dates } \\
& $29 / 06 / 2013$ & $09 / 08 / 2013$ & $14 / 08 / 2013$ \\
\hline $\begin{array}{l}\text { Simulation setting } \\
\text { Start simulation day } \\
\text { (dd.mm.yyyy) }\end{array}$ & 29.06 .2013 & 09.08 .2013 & 13.08 .2013 \\
$\begin{array}{l}\text { Start simulation time } \\
\text { (hh.mm.ss) }\end{array}$ & $06: 00: 00$ & $06: 00: 00$ & $06: 00: 00$ \\
$\quad \begin{array}{l}\text { Total simulation time in } \\
\text { hours (h) }\end{array}$ & 24 & 24 & 24 \\
$\begin{array}{l}\text { Save model state (min) } \\
\text { Meteorological inputs }\end{array}$ & 10 & 10 & 10 \\
$\quad \begin{array}{l}\text { Wind speed in } 10 \mathrm{~m} \\
\text { above ground (m/s) }\end{array}$ & 1.0 & 0 & 0.9 \\
$\begin{array}{l}\text { Wind direction ( }{ }^{\circ} \text { ) } \\
\text { Initial temperature } \\
\text { atmosphere (K) }\end{array}$ & 135 & 112.5 & 225 \\
$\begin{array}{l}\text { Specific humidity in } \\
\text { 2500 m (g/kg) }\end{array}$ & 293.4 & 301.2 & 300.1 \\
$\begin{array}{l}\text { Relative humidity in } \\
2 \text { m (\%) }\end{array}$ & 3.48 & 3.52 & 3.52 \\
$\begin{array}{l}\text { Albedo of walls } \\
\text { Albedo of roofs }\end{array}$ & 81.3 & 88.5 & 74.7 \\
\hline
\end{tabular}

(nighttime), which is equivalent to the actual site measurements. The distribution of the ENVI-met results was analyzed using the ArcGIS 9.3 program.

Since information on soil ingredients and vegetation used as input data for ENVI-met analysis (infrared and visible range and calculations of radiation) was all measured using the values or formulas provided by the program, there are considerable gaps between the target areas. The accuracy of the models utilized must be validated using actual field data. There have been a number of recent tests $[18,36,37$, 45-47] of the accuracy of the ENVI-met model. For this study, the results of the ENVI-met model were validated by comparison with field data generated at a receptor installed at the measurement points.

2.4. Space Design. Space design was established by considering green-area development and increases in the reflectivity of each target area (Table 3). The green areas were developed by growing broad-leaf trees to a height of $2 \mathrm{~m}$ or by growing grass $10 \mathrm{~cm}$ high in parking lots and squares distributed within the target areas. On rooftops, green areas were expanded using $1.5 \mathrm{~m}$ high trees. Design changes intended to increase albedo have been studied actively in previous research using ENVI-met [48]. Based on these previous results, an albedo increase of 0.2 was added to the ground cover data provided by the ENVI-met program, mostly by applying them to parking facilities or building roofs.

Following analysis of the target areas, the urban park area was found to consist of scattered sections covered by marble and granite. Green ground cover was set up in these areas (U1 , Table 3) by growing grass, which increased their reflectivity 
TABLE 3: Space design plan for each target area.

\begin{tabular}{ll}
\hline Site & Green space formation \\
\hline Urban park &
\end{tabular}

$<\mathrm{U}-1>$

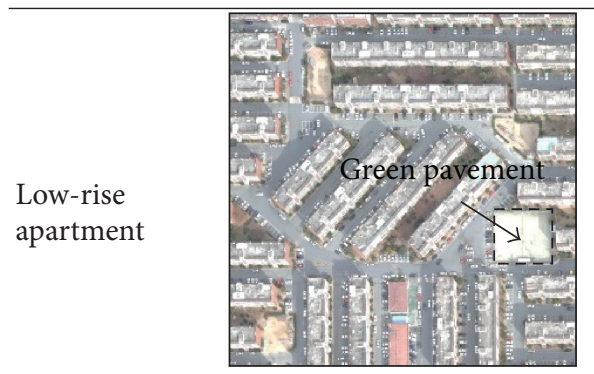

$<\mathrm{L}-1>$

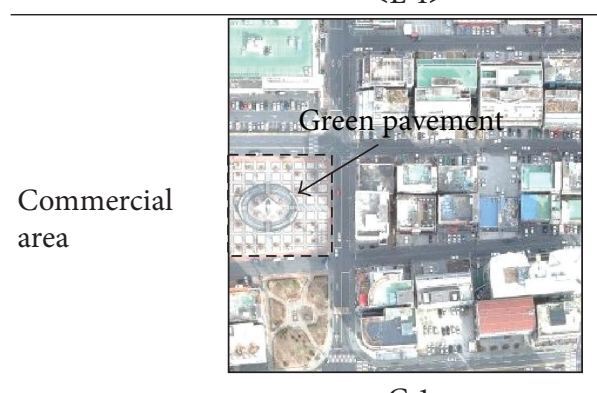

$<\mathrm{C}-1>$

Single
residential
$<$ S-1 $>$

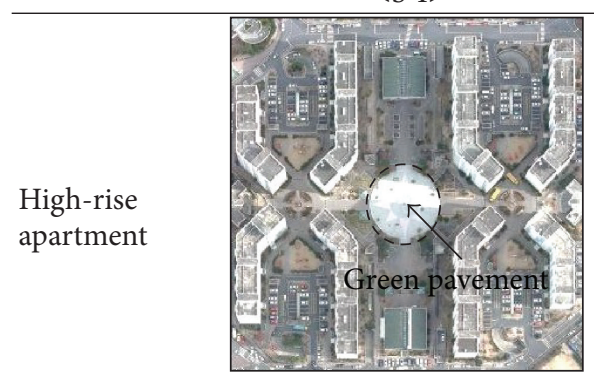

$<\mathrm{H}-1>$

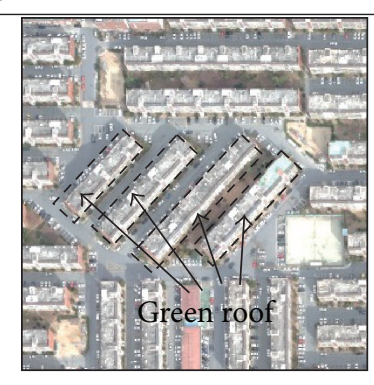

$<\mathrm{L}-2>$

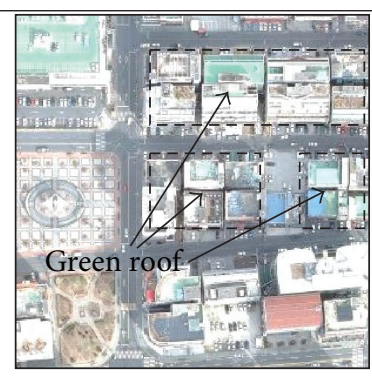

$<\mathrm{C}-2>$

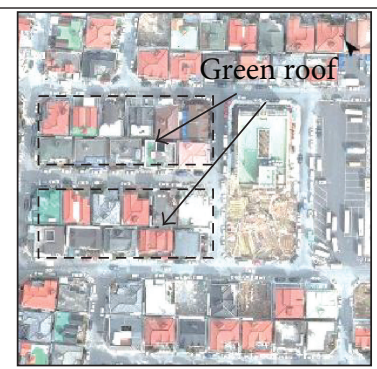

$<\mathrm{S}-2>$

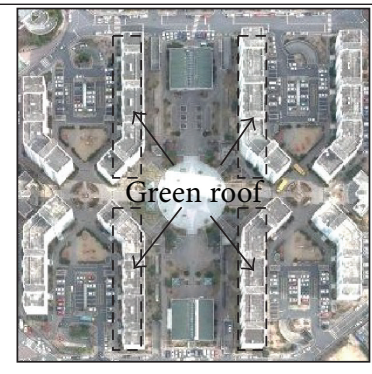

$<\mathrm{H}-2>$

Space design

Covering material replacement

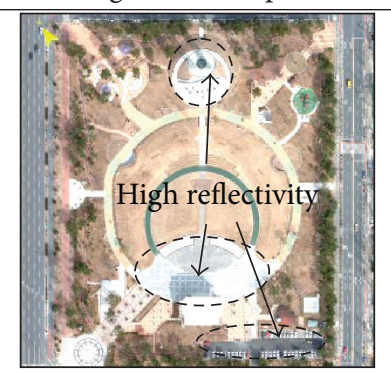

$<\mathrm{U}-2>$

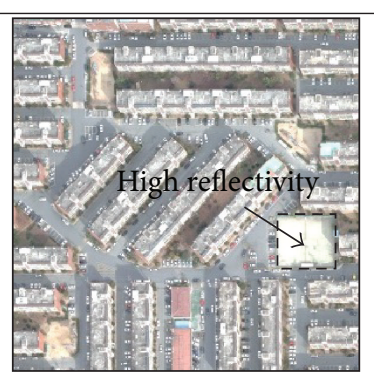

$<\mathrm{L}-3>$

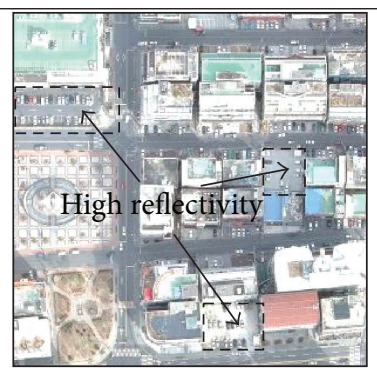

$<\mathrm{C}-3>$

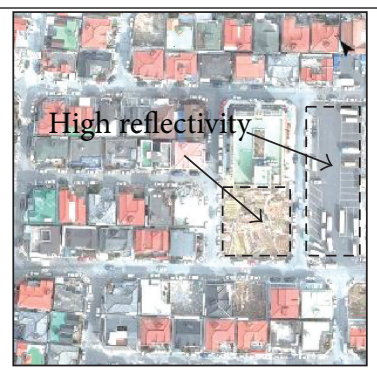

$<$ S-3 $>$

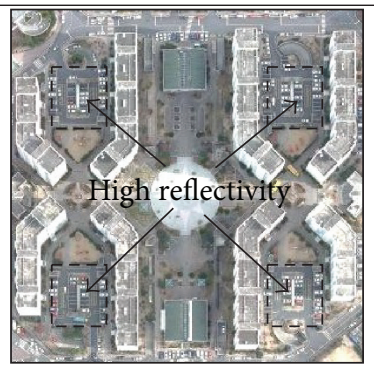

$<\mathrm{H}-3>$

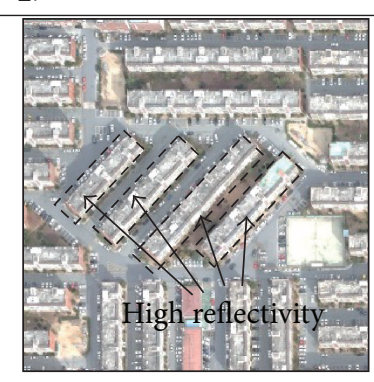

$<\mathrm{L}-4>$

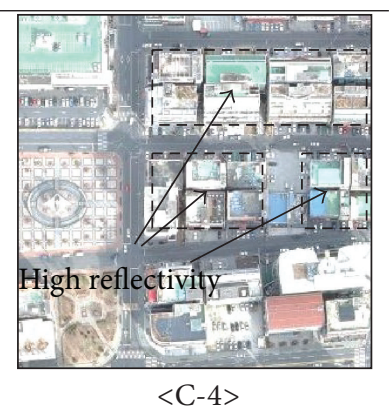

$<\mathrm{C}-4>$

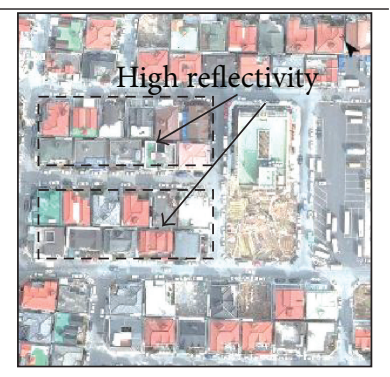

$<$ S-4>

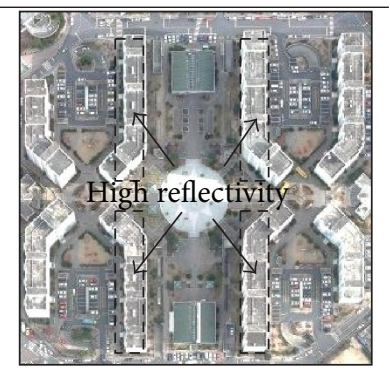

$<\mathrm{H}-4>$ 
(U-2, Table 3). In the low-rise apartment area, the parking lot was equipped (L-1, Table 3 ) with trees and the roof cover was replaced (L-3, Table 3 ) with high-reflectivity material. Furthermore, for each of the four buildings located at the center of the analysis area, a green roof ( $1.5 \mathrm{~m}$ high) was built (L-2, Table 3 ) and the reflectivity of the roof was increased by applying (L-4, Table 3) high-reflectivity roof-cover materials. In the commercial area, a green area was formed (C-1, Table 3). In the fountain square, green roofs (C-2, Table 3) were built on the high-rise buildings, and their reflectivity was increased (C-4, Table 3 ). The reflectivity of the coating materials in the parking lot was also increased (C-3, Table 3) by 0.2 . In the single residential area, plants were grown (S1, Table 3 ) in the parking facilities, and its reflectivity was increased (S-3, Table 3). Green plants were placed on the roofs of approximately 20 households (S-2, Table 3), and their reflectivity was increased (S-4, Table 3 ). In the highrise apartment area, greenery was added (H-1, Table 3 ) to tile-covered squares; for the four buildings located at the center, rooftop greening $(\mathrm{H}-2$, Table 3$)$ and reflectivity $(\mathrm{H}-4$, Table 3) were increased. Furthermore, the asphalt material of the parking lot located between the buildings was replaced (H-3, Table 3) with a high-reflectivity material.

Simulations were conducted for each target area using the ENVI-met model, considering the plan adopted for the space design. Improvements in the thermal environment were equated by comparing the spatial changes in climate according to the space designs, using ArcGIS 9.3. The ENVImet model time was set as 09 August 2013, which corresponded to the highest recorded field measured temperature. The comparisons were done using the simulated $14 \mathrm{~h}$ results.

\section{Results and Discussion}

3.1. Field Measurement Results. Table 4 shows the field temperature values by measurement point. The average temperature $\left(29.5^{\circ} \mathrm{C}\right)$ occurred on 29 June 2013, reaching the highest average $\left(35.4^{\circ} \mathrm{C}\right)$ on 09 August 2013. On 14 August 2013 , the average nighttime temperature was $29.5^{\circ} \mathrm{C}$. Among the different measurement areas, the high-rise commercial and single residential areas had high average temperatures (29 June: $30.0^{\circ} \mathrm{C}, 09$ August: $35.8^{\circ} \mathrm{C}$, and 14 August: $29.2^{\circ} \mathrm{C}$ ). These two areas also had a high density of artificial structures composed of asphalt and concrete. The high-rise apartment area had relatively more greenery and shade due to the presence of taller buildings. This area had lower average temperatures than the others (29 June: $29.4^{\circ} \mathrm{C}, 09$ August: $34.7^{\circ} \mathrm{C}$, and 14 August: $28.4^{\circ} \mathrm{C}$ ). The measurement points (points 1-4, Table 4) in the northern part of the urban park area were strongly affected by the surrounding area. During the field analysis, moderate winds $\left(1-2 \mathrm{~ms}^{-1}\right)$ were experienced, resulting in considerably lower temperatures than at other measurement points.

3.2. Accuracy of the ENVI-Met Model. Figure 4 shows the results of modeled temperature and measured temperature in each measurement area. Measured temperatures turned out to be higher than modeled temperatures. A scatter plot
TABLE 4: Field temperature measurement $\left({ }^{\circ} \mathrm{C}\right)$.

\begin{tabular}{|c|c|c|c|c|}
\hline ID & Surface cover & $06 / 29 / 2013$ & $08 / 09 / 2013$ & $08 / 14 / 2013$ \\
\hline \multicolumn{5}{|c|}{ Urban park } \\
\hline 1 & Granite & 28.3 & 37.0 & 28.4 \\
\hline 2 & Brick & 28.7 & 37.3 & 29.1 \\
\hline 3 & Brick & 28.9 & 36.9 & 29.0 \\
\hline 4 & Lawn & 29.0 & 35.9 & 28.9 \\
\hline 5 & Urethane & 29.1 & 35.4 & 28.8 \\
\hline 6 & Wooden board & 29.2 & 35.3 & 28.7 \\
\hline 7 & Brick & 29.1 & 34.8 & 28.6 \\
\hline 8 & Granite & 29.1 & 34.7 & 28.5 \\
\hline 9 & Lawn & 29.2 & 34.6 & 28.4 \\
\hline & Mean & 29.0 & 35.7 & 28.7 \\
\hline \multicolumn{5}{|c|}{ Low-rise APT } \\
\hline 10 & Asphalt & 29.8 & 35.0 & 28.4 \\
\hline 11 & Sand & 29.9 & 35.1 & 28.5 \\
\hline 12 & Asphalt & 29.9 & 35.2 & 28.5 \\
\hline 13 & Asphalt & 30.0 & 35.4 & 28.5 \\
\hline 14 & Concrete & 30.3 & 35.4 & 28.6 \\
\hline \multirow[t]{2}{*}{15} & Asphalt & 30.4 & 35.4 & 28.6 \\
\hline & Mean & 30.1 & 35.3 & 28.5 \\
\hline \multicolumn{5}{|c|}{ Commercial area } \\
\hline 16 & Asphalt & 29.9 & 35.6 & 29.1 \\
\hline 17 & Brick & 30.1 & 35.8 & 29.2 \\
\hline \multirow[t]{2}{*}{18} & Gravel & 30.0 & 35.9 & 29.2 \\
\hline & Mean & 30.0 & 35.8 & 29.2 \\
\hline \multicolumn{5}{|c|}{ Single residential } \\
\hline 19 & Asphalt & 29.8 & 35.6 & 29.1 \\
\hline 20 & Asphalt & 29.9 & 35.8 & 28.9 \\
\hline 21 & Gravel & 30.0 & 35.8 & 28.8 \\
\hline \multirow[t]{2}{*}{22} & Asphalt & 29.9 & 35.9 & 28.7 \\
\hline & Mean & 29.9 & 35.8 & 28.9 \\
\hline \multicolumn{5}{|c|}{ High-rise APT } \\
\hline 23 & Sand & 29.5 & 34.7 & 28.4 \\
\hline 24 & Brick & 29.5 & 34.7 & 28.4 \\
\hline 25 & Brick & 29.3 & 34.7 & 28.4 \\
\hline 26 & Tile & 29.3 & 34.6 & 28.4 \\
\hline \multirow[t]{2}{*}{27} & Brick & 29.3 & 34.6 & 28.4 \\
\hline & Mean & 29.4 & 34.7 & 28.4 \\
\hline
\end{tabular}

was examined to determine the accuracy of the modeled temperature, and the result is shown in Figure 5. The temperatures of points 1-4 (Table 4), corresponding to the urban park area, were excluded because they were severely affected by the surrounding area. The coefficient of determination was very high on 09 August 2013 (0.627) and on 14 August 2013 (0.613). Ng et al. [18] and Yang et al. [49] found the coefficient of determination to be $0.6-0.7$ and 0.94 . The former was a bit higher and the latter much higher, than the values determined in the present study (Figure 5). In previous studies, the daily variations at each measurement point of the model and field data were compared. In the present study, the data at the same time were compared for the various points. 


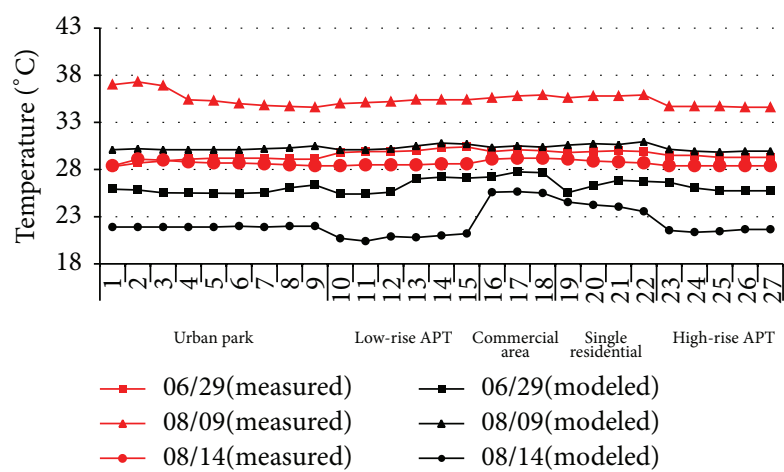

FIgURE 4: Comparison of modeled and measured temperatures at each measurement point.

Therefore, direct comparison of these results with those of earlier studies is not possible. Nevertheless, the temperature data from the model and field measurements showed high correlation, and it was determined that the ENVI-met results were suitable. The root-mean-square error (RMSE) showed a difference of $3.4^{\circ} \mathrm{C}$ on 29 June $2013,4.6^{\circ} \mathrm{C}$ on 09 August 2013 , and $6.5^{\circ} \mathrm{C}$ on 14 August 2013. The field measurement data were consistently higher. The mean difference between the ENVI-met model and field measurements reported by Middel et al. [37], Yang et al. [49], and Chow et al. [45] were $1.4-2.0,1.01$, and $1.53^{\circ} \mathrm{C}$, respectively. In sharp contrast, a study by Park [50] showed a mean difference of $7.0-11.0^{\circ} \mathrm{C}$. However, the remaining literature, showed a temperature difference of approximately $3^{\circ} \mathrm{C}$ between the model and field measurements over the course of $14 \mathrm{~h}$. This is in agreement with the findings of this study. Therefore, it was found that the difference between the model and field measurements in this study was not significant, compared to previous studies, and that the correlation was very high. Thus, it was concluded that the accuracy of the model was sufficient.

3.3. Thermal Environment Improvement Effect. Table 5 and Figure 6 show the results of the analysis of temperature changes according to space design, using the ENVI-met model. Table 6 shows the changes in surface temperature at the measurement points.

3.3.1. Urban Park. The temperature provided by the ENVImet model for 09 August 2013, at 14:00, on the road east of the park was $>31^{\circ} \mathrm{C}$, whereas that for the inner park was lower $\left(<30.4^{\circ} \mathrm{C}\right)$. When the artificial material covering the ground inside the park was replaced with grass (U-1), the average temperature increased by $0.05^{\circ} \mathrm{C}$. Considering the uncertainty level of the model, this change was considered insignificant. Moreover, the temperature increased by $0.15^{\circ} \mathrm{C}$ when the reflectivity was increased (U-2). However, unlike in the unaltered park space, a road located in the eastern part of the park exhibited lower temperatures. This was because of changes in the microclimate after the material covering of the ground was replaced (Figure 5). Therefore, in the urban park area, establishing grass as the ground cover in place of artificial coverings, or increasing the reflectivity of the ground

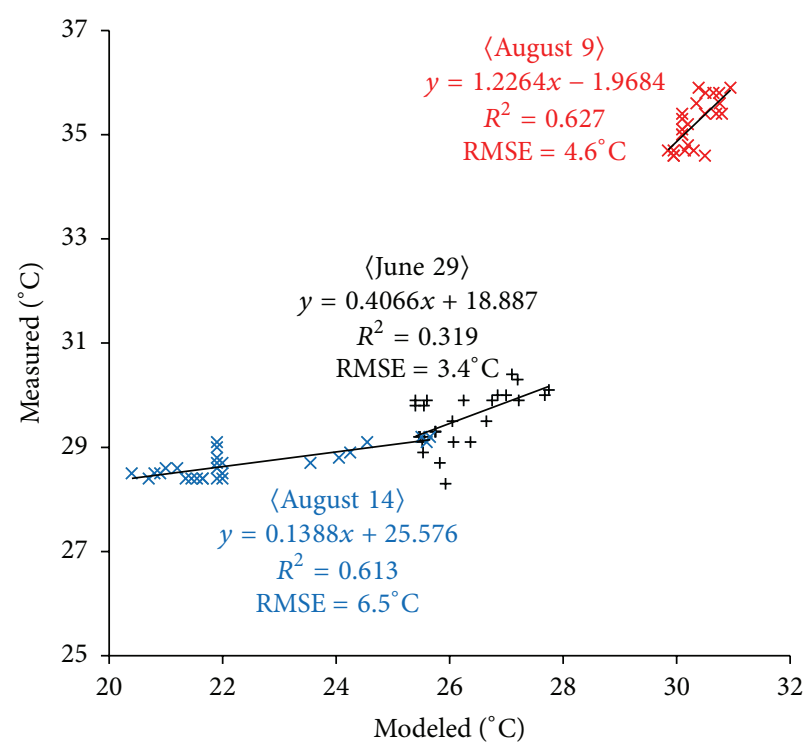

Figure 5: Comparison of the 2013 ENVI-met modeled and field measured temperatures for the following: 29 June: lower left set $(x)$, 09 August: central set (+), and 14 August: upper right set (*).

TABLE 5: Changes in temperature by space design.

\begin{tabular}{lcccc}
\hline Site & \multicolumn{5}{c}{ Temperature changes $\left({ }^{\circ} \mathrm{C}\right)$} \\
\hline \multirow{2}{*}{ Urban park } & $\mathrm{U}-1$ & $\mathrm{U}-2$ & & \\
& +0.05 & +0.15 & & \\
\hline \multirow{2}{*}{ Low-rise apartment } & $\mathrm{L}-1$ & $\mathrm{~L}-2$ & $\mathrm{~L}-3$ & $\mathrm{~L}-4$ \\
& +0.15 & -0.05 & +0.15 & +0.18 \\
\hline \multirow{2}{*}{ Commercial area } & $\mathrm{C}-1$ & $\mathrm{C}-2$ & $\mathrm{C}-3$ & $\mathrm{C}-4$ \\
& -0.21 & -0.07 & +0.15 & +0.17 \\
\hline \multirow{2}{*}{ Single residential } & $\mathrm{S}-1$ & $\mathrm{~S}-2$ & $\mathrm{~S}-3$ & $\mathrm{~S}-4$ \\
& -0.28 & -0.01 & +0.18 & +0.11 \\
\hline \multirow{2}{*}{ High-rise apartment } & $\mathrm{H}-1$ & $\mathrm{H}-2$ & $\mathrm{H}-3$ & $\mathrm{H}-4$ \\
& +0.08 & +0.46 & +0.06 & +0.06 \\
\hline
\end{tabular}

cover, resulted in an increase in the average temperatures. However, these alterations decreased the temperatures of the surrounding areas.

3.3.2. Low-Rise Apartment Area. The results of the temperature distribution analysis, given the space design of the lowrise apartment area, showed that the initial temperature in the parking lot was $30.8-31.0^{\circ} \mathrm{C}$, whereas, in the south the temperature was comparatively high, measuring $31.0-31.2^{\circ} \mathrm{C}$. Conversely, the analysis showed that the temperature was less than $30.6^{\circ} \mathrm{C}$ in most areas. When the concrete material of the parking lot was replaced (L-1) with grass, the surface temperature decreased significantly $\left(8.6^{\circ} \mathrm{C}\right)$; however, the average temperature increased by $0.15^{\circ} \mathrm{C}$ and the temperature of the parking lot increased to $31.0-31.2^{\circ} \mathrm{C}$. As roof-top greening was applied to the buildings (L-2), the average temperature decreased by $0.05^{\circ} \mathrm{C}$, and the surface temperature of the surrounding area decreased by $1.7-5.0^{\circ} \mathrm{C}$. Once the reflectivity of the cover materials (L-3) of the parking lot 

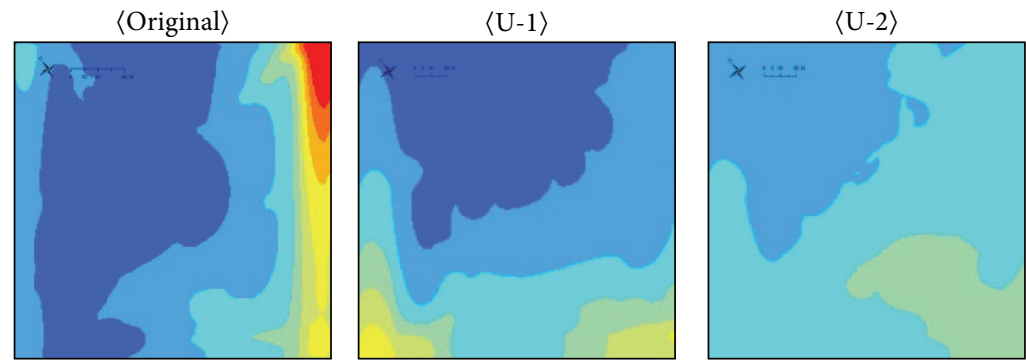

(a)
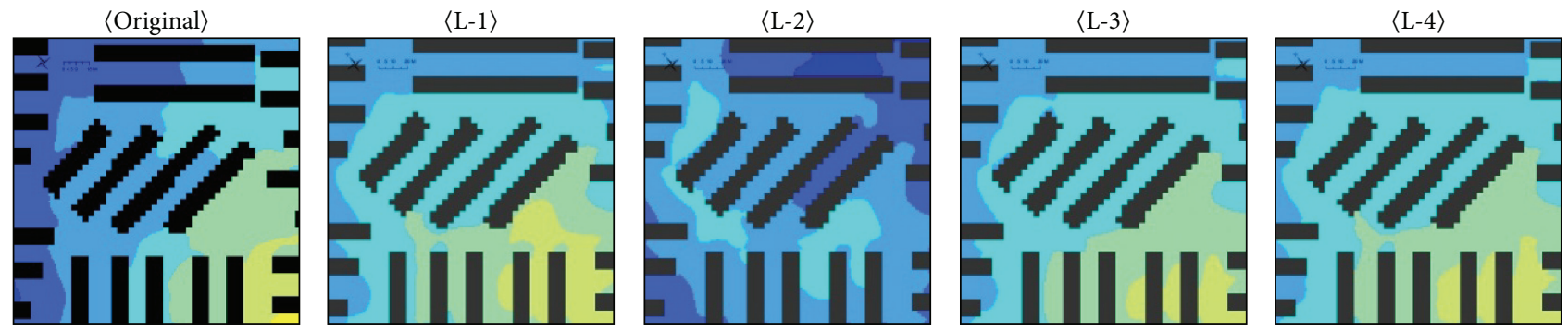

(b)
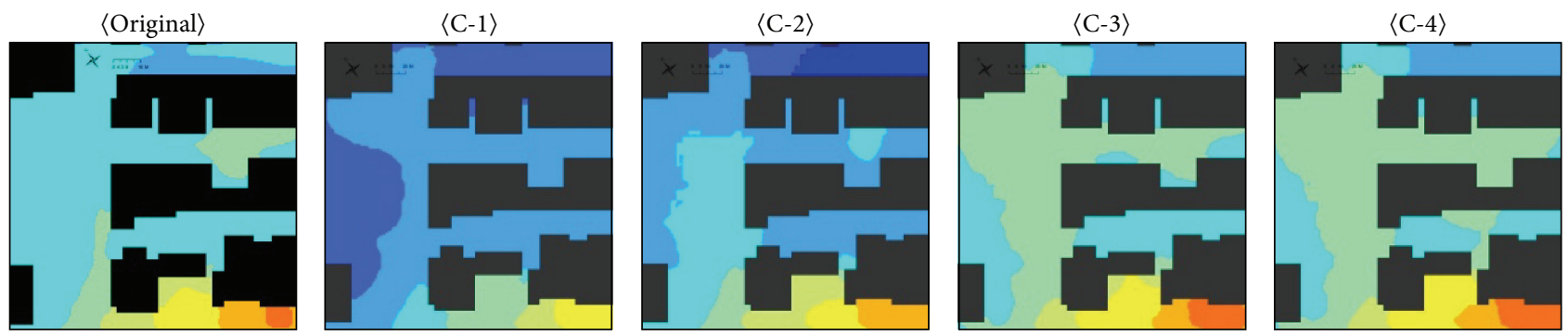

(c)
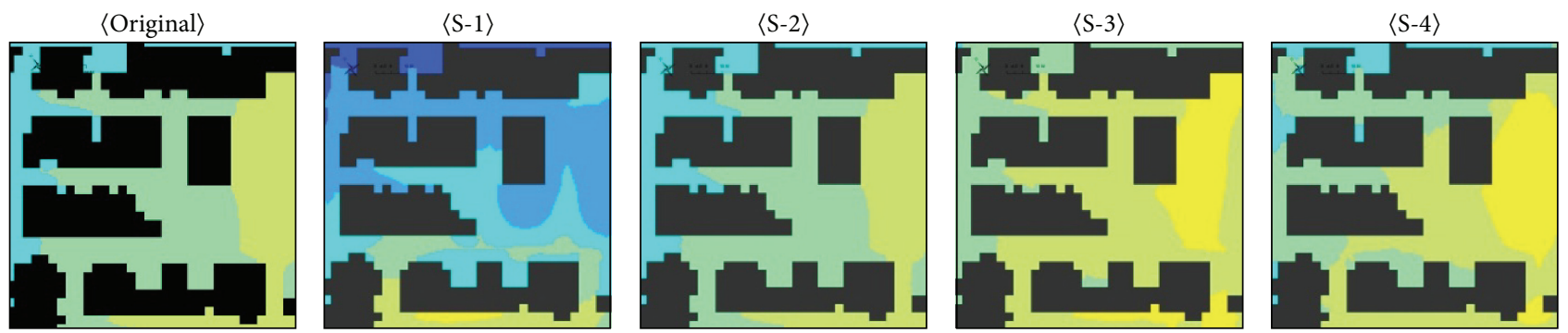

(d)

$\langle$ Original〉

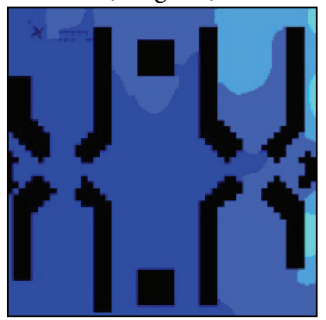

$\langle\mathrm{H}-1\rangle$

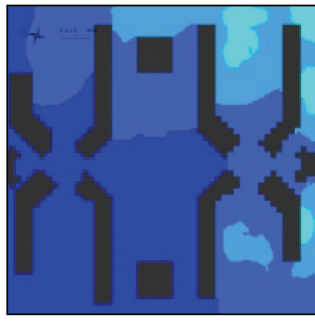

$\langle\mathrm{H}-2\rangle$

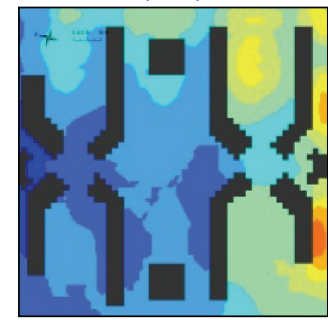

$\square 30.6-30.8^{\circ} \mathrm{C}$

$\square 30.8-31.0^{\circ} \mathrm{C}$
$\langle\mathrm{H}-3\rangle$

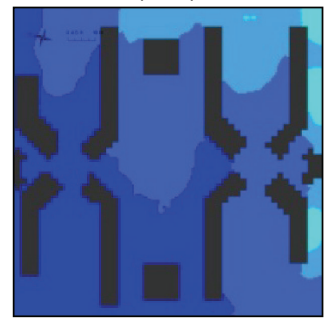

$31.0-31.2^{\circ} \mathrm{C}$

$31.2-31.4^{\circ} \mathrm{C}$
$\langle\mathrm{H}-4\rangle$

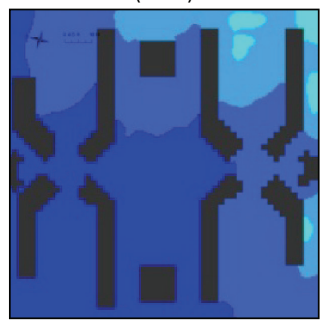

$31.4-31.6^{\circ} \mathrm{C}$

Over $31.6^{\circ} \mathrm{C}$

(e)

FIGURE 6: Changes in temperature distribution according to the scenario settings: (a) urban park area, (b) low-rise apartment area, (c) highrise commercial area, (d) single residential area, (e) high-rise apartment area. 
TABLE 6: Differences in surface temperature of existing spaces and space design.

\begin{tabular}{|c|c|c|c|c|c|c|c|c|c|c|c|c|c|c|c|c|c|c|}
\hline \multirow{3}{*}{ Point } & \multicolumn{18}{|c|}{ Scenario } \\
\hline & \multicolumn{2}{|c|}{ Urban park } & \multicolumn{4}{|c|}{ Low-rise apartment } & \multicolumn{4}{|c|}{ Commercial area } & \multicolumn{4}{|c|}{ Single residential } & \multicolumn{4}{|c|}{ High-rise apartment } \\
\hline & U-1 & $\mathrm{U}-2$ & L-1 & $\mathrm{L}-2$ & $\mathrm{~L}-3$ & $\mathrm{~L}-4$ & C-1 & $\mathrm{C}-2$ & $\mathrm{C}-3$ & $\mathrm{C}-4$ & S-1 & S-2 & S-3 & S-4 & $\mathrm{H}-1$ & $\mathrm{H}-2$ & $\mathrm{H}-3$ & $\mathrm{H}-4$ \\
\hline \multicolumn{19}{|c|}{ Urban park } \\
\hline 1 & +6.6 & +12.1 & & & & & & & & & & & & & & & & \\
\hline 2 & -2.4 & -1.7 & & & & & & & & & & & & & & & & \\
\hline 3 & +2.9 & -1.7 & & & & & & & & & & & & & & & & \\
\hline 4 & +1.3 & +1.9 & & & & & & & & & & & & & & & & \\
\hline 5 & +12.5 & +8.3 & & & & & & & & & & & & & & & & \\
\hline 6 & +2.9 & -0.7 & & & & & & & & & & & & & & & & \\
\hline 7 & +2.3 & -2.3 & & & & & & & & & & & & & & & & \\
\hline 8 & -4.7 & -0.8 & & & & & & & & & & & & & & & & \\
\hline 9 & +0.4 & +1.3 & & & & & & & & & & & & & & & & \\
\hline \multicolumn{19}{|c|}{ Low-rise apartment } \\
\hline 10 & & & -4.4 & -1.7 & -3.1 & -4.0 & & & & & & & & & & & & \\
\hline 11 & & & +0.1 & +1.1 & +0.7 & +0.8 & & & & & & & & & & & & \\
\hline 12 & & & -5.0 & -5.0 & -5.1 & -5.0 & & & & & & & & & & & & \\
\hline 13 & & & +1.6 & +1.4 & +1.6 & +1.6 & & & & & & & & & & & & \\
\hline 14 & & & -8.6 & +2.7 & +0.7 & +3.0 & & & & & & & & & & & & \\
\hline 15 & & & -4.2 & -5.1 & -4.8 & -4.8 & & & & & & & & & & & & \\
\hline \multicolumn{19}{|c|}{ Commercial area } \\
\hline 16 & & & & & & & -1.2 & -0.6 & -0.3 & -0.2 & & & & & & & & \\
\hline 17 & & & & & & & -11.0 & +2.8 & +2.5 & +2.6 & & & & & & & & \\
\hline 18 & & & & & & & +0.0 & +8.8 & +13.5 & +13.7 & & & & & & & & \\
\hline \multicolumn{19}{|c|}{ Single residential } \\
\hline 19 & & & & & & & & & & & -0.4 & +0.1 & +2.5 & +2.4 & & & & \\
\hline 20 & & & & & & & & & & & -0.5 & -0.1 & +1.8 & +1.5 & & & & \\
\hline 21 & & & & & & & & & & & -7.1 & -0.1 & +10.2 & +12.0 & & & & \\
\hline 22 & & & & & & & & & & & -20.6 & -3.4 & -2.5 & -3.8 & & & & \\
\hline \multicolumn{19}{|c|}{ High-rise apartment } \\
\hline 23 & & & & & & & & & & & & & & & +0.2 & +0.6 & +0.2 & +0.2 \\
\hline 24 & & & & & & & & & & & & & & & +0.1 & +0.9 & +0.0 & +0.0 \\
\hline 25 & & & & & & & & & & & & & & & +0.6 & +1.6 & +0.7 & +0.7 \\
\hline 26 & & & & & & & & & & & & & & & -3.9 & +3.2 & +10.8 & +0.4 \\
\hline 27 & & & & & & & & & & & & & & & +1.6 & +1.8 & +1.6 & +1.4 \\
\hline
\end{tabular}

and the building rooftop (L-4) was increased, the average temperature increased by 0.15 and $0.18^{\circ} \mathrm{C}$, respectively. It was also observed that the temperature around the parking lot and building increased from 30.4 to $30.8^{\circ} \mathrm{C}$ and that the temperature of the existing space rose by the same amount (from 30.2 to $30.6^{\circ} \mathrm{C}$, for an increase of $0.4^{\circ} \mathrm{C}$ in both cases).

3.3.3. Commercial Area. In the commercial area, the temperature in the southern section was generally higher than $31.0^{\circ} \mathrm{C}$. For C-1 (Figure 5), which was designed with a green park, the average temperature decreased by $0.21^{\circ} \mathrm{C}$, compared with the existing space, and the temperature was found to be less than $30.4^{\circ} \mathrm{C}$ in most areas. The surface temperature of the measure points with green areas decreased by about $11^{\circ} \mathrm{C}$. When the green spaces of the commercial area were developed, a distinct temperature reduction effect was confirmed.
Following rooftop greening (C-2), the surface temperature of the surrounding area increased slightly; however, the average temperature decreased by $0.07^{\circ} \mathrm{C}$. Most areas showed a lower temperature distribution $\left(30.2-30.6^{\circ} \mathrm{C}\right)$ than that of the existing space $\left(30.4-30.6^{\circ} \mathrm{C}\right)$. As the reflectivity of the cover material (C-3) of the parking lot and building rooftop (C-4) was increased, the average temperature increased by 0.15 and $0.17^{\circ} \mathrm{C}$, respectively, compared with the existing space; many of the areas were observed to be within the temperature range of 30.6 to $30.8^{\circ} \mathrm{C}$.

3.3.4. Single Residential Area. The existing single residential area mostly showed a temperature distribution ranging between 30.6 and $31.0^{\circ} \mathrm{C}$. When green covering was added to the parking lot $(\mathrm{S}-1)$, the average temperature decreased by $0.28^{\circ} \mathrm{C}$, and the surface temperature range was between 
7.1 and $20.6^{\circ} \mathrm{C}$, showing a significant decrease. After the rooftop greening was applied (S-2), the average temperature decreased by $0.01^{\circ} \mathrm{C}$, which is insignificant considering the existing space. Moreover, the surface temperatures around the buildings decreased slightly. When the reflectivity of the materials in the parking lot (S-3) and the building rooftop (S4) were increased, the average temperature increased by 0.18 and $0.11^{\circ} \mathrm{C}$, respectively. As the reflectivity of the parking lot was increased, the surface temperature at the measurement point adjacent to the building increased by $10.2^{\circ} \mathrm{C}$, whereas the surface temperature decreased by $2.5^{\circ} \mathrm{C}$ at a measurement point far away from the building. Similarly, when the reflectivity of the rooftop was increased, the surface temperature at the measurement point adjacent to the building increased by $12.0^{\circ} \mathrm{C}$, but the surface temperature decreased by $3.8^{\circ} \mathrm{C}$ at the measurement point far away from the building.

3.3.5. High-Rise Apartment Area. The temperatures in the existing space of the high-rise apartment area were typically below $30.0^{\circ} \mathrm{C}$. Following the space design, the average temperatures increased, but there were no significant differences $\left(\mathrm{H}-1+0.08^{\circ} \mathrm{C}, \mathrm{H}-3+0.06^{\circ} \mathrm{C}\right.$, and $\left.\mathrm{H}-4+0.06^{\circ} \mathrm{C}\right)$ except after rooftop greening was performed $\left(\mathrm{H}-2+0.46^{\circ} \mathrm{C}\right)$. The surface temperature at $\mathrm{H}-3$, where the reflectivity of the cover materials of the parking lot was increased, showed a significant increase in temperature of $10.8^{\circ} \mathrm{C}$ compared to the surface temperature of the existing space. An increase in surface temperature was observed at all measurement points except for $\mathrm{H}-1$, which was designed with trees.

3.4. Discussion. When a green area was developed near trees in the space design plan, commercial and single residential area land-use types that were mostly covered in artificial materials, such as asphalt and concrete, showed significant decreases in temperature. The urban park, lowrise apartment, and high-rise apartment areas, all of which had comparatively rich green areas, exhibited low surface temperatures; however, after similar changes were applied the temperatures increased. After rooftop greening was performed, the decrease in temperature was not as significant as it was when a green park was formed. The temperatures were slightly lower in the low-rise apartment and commercial areas than in the single residential area. The formation of green areas resulted in different effects depending on the spatial characteristics of the surrounding area. Furthermore, it was revealed that the temperature-reducing effect of green areas became more distinct as the density of artificial structures within the space increased.

When the reflectivity of the cover material was increased, an increase in temperature was observed; the surface temperature increased as the distance between the measurement point and the building decreased. Taha et al. [51] compared surface temperatures with reflectivity for a variety of cover materials. White elastomeric coatings (albedo of 0.72) exhibited surface temperatures that were $45^{\circ} \mathrm{C}$ lower than black coating (albedo of 0.08). Furthermore, Li et al. [25] examined the temporal changes in reflectivity in relation to the colors of cover materials such as concrete and asphalt. They observed that surface temperature decreased as reflectivity increased. This is because when reflectivity is increased, the amount of net-radiative energy accumulating on the surface decreases. However, the analytical results of the present study showed that surface temperatures increased slightly even when reflectivity increased. It was concluded that the reflected radiation energy was absorbed by the surrounding buildings and was consequently reradiated to the surface from the building. The observed low surface temperatures at the measurement points in the park (without buildings) and at a distance from the buildings confirm this conclusion. Additionally, studies by Lau and Yang [24], Lin et al. [26], and Wang et al. [32] showed that although surface temperature decreased as reflectivity increased, it had a negative effect on the physical and mental health of pedestrians. Yang et al. [33] showed that when the reflectivity of the land surface was increased to 0.4 , the physiological equivalent temperature increased by $5-7^{\circ} \mathrm{C}$, thereby reducing the level of overall outdoor thermal comfort. A number of studies [27, 29, 34, 52-54] have demonstrated that a reduction in building energy and mitigation of the urban heat-island effect can be achieved by increasing the reflectivity of roof surfaces. However, these studies have not shown that thermal comfort is improved in outdoor spaces with a high density of buildings; therefore, it is necessary to establish the reflectivity of cover materials, which is one aspect of the space design plan, while considering the arrangement of the surrounding buildings.

\section{Conclusions}

In this study, an effective application plan was established for improving the thermal environment in the urban areas of Changwon City, South Korea. The plan was based on space design, and it included the development of a green area and increasing the reflectivity of ground and building cover materials for various types of land use. The results from analysis of the changes caused by this plan are summarized below.

The results of the field measurements showed that the highest temperature occurred on 09 August $2013,\left(35.4^{\circ} \mathrm{C}\right)$, while on 29 June 2013 the temperature was $29.5^{\circ} \mathrm{C}$. The average nighttime temperature $\left(28.7^{\circ} \mathrm{C}\right)$ was recorded on 14 August 2013. Based on the accuracy of the ENVI-met model, it was concluded that the temperatures exhibited a high RMSE; however, analysis showed that the coefficient of determination of the linear regression on 09 August 2013 and 14 August 2013 exceeded 0.6, thereby increasing the explanatory power of the ENVI-met model. The analysis of the temperature changes (according to the space design), taking into account increases in reflectivity and development of green areas for different types of land use, showed distinct temperature reduction effects due to creation of green spaces in areas where buildings and artificial cover materials were densely distributed (i.e., commercial and single residential areas). The urban park, low-rise apartment, and high-rise apartment areas, with relatively many green areas, were predicted to exhibit temperature increases. When the reflectivity of the cover materials was increased, those areas exhibited 
increases in temperature; when the reflectivity in areas with high building density was increased, the surface temperature increased.

The results suggest that the effects of thermal improvement due to green area development and increasing reflectivity differ depending on land use. This is because different land uses have different building arrangements and proportions of cover materials. To achieve the optimal thermal environment improvement effect at an urban and environmental planning level, it is necessary to consider the spatial characteristics of the land-use types and the surrounding areas appropriately. For example, the single residential or apartment areas, which had copious green space, showed an insignificant decrease in temperature even after rooftop greening and creation of a park. Therefore, in order to improve the thermal environment, it is more beneficial to increase the effect of shading by varying the arrangement of buildings, rather than by developing a green area. Furthermore, areas with a high density of artificial cover materials and of buildings displayed increases in air and surface temperatures after increasing the reflectivity of cover materials. Furthermore, this study showed that in spaces where artificial cover materials and buildings are concentrated the increased reflectivity of cover materials rather led to an increase in temperature. To clarify the temperature reduction effect according to cover materials of high reflectivity, it is also necessary to consider urban geometry (e.g., the sky-view factor), as well as the reflectivity or emissivity of building walls. These should be considered in future research.

In order to validate the accuracy of the model, the results of the ENVI-met model were compared with temperatures measured in the field, and a high correlation was found. However, there was a significant difference in the RMSE. This is because the ENVI-met model only takes into consideration the geographical location and initial weather conditions, without accounting for seasonal impacts. To solve this problem, a method must be utilized that can simulate the changes in climate for longer periods. In addition to temperature, other factors (e.g., radiation flux, wind speed, humidity, and surface temperature) also affect the thermal environment; therefore, it is necessary to consider the validity of the model with respect to these various factors. It is believed that an optimal space design plan for the improvement of the thermal environment can be provided, at the urban and environmental planning level, by taking into account a wider range of factors.

\section{Conflict of Interests}

The authors declare that there is no conflict of interests regarding the publication of this paper.

\section{Acknowledgment}

This research was supported by the Basic Science Research Program through the National Research Foundation of Korea (NRF) funded by the Ministry of Education, Science and Technology (no. 2013-0095-0000).

\section{References}

[1] Y. Gao, J. Xu, S. Yang et al., "Cool roofs in China: policy review, building simulations, and proof-of-concept experiments," Energy Policy, vol. 74, pp. 190-214, 2014.

[2] R. Levinson and H. Akbari, "Potential benefits of cool roofs on commercial buildings: conserving energy, saving money, and reducing emission of greenhouse gases and air pollutants," Energy Efficiency, vol. 3, no. 1, pp. 53-109, 2010.

[3] L. Shashua-Bar and M. E. Hoffman, "Vegetation as a climatic component in the design of an urban street: an empirical model for predicting the cooling effect of urban green areas with trees," Energy and Buildings, vol. 31, no. 3, pp. 221-235, 2000.

[4] F. Wilmers, "Effects of vegetation on urban climate and buildings," Journal of Energy and Building, vol. 15, no. 3-4, pp. 507514,1990

[5] M. Taleghani, M. Tenpierik, A. van den Dobbelsteen, and D. J. Sailor, "Heat in courtyards: a validated and calibrated parametric study of heat mitigation strategies for urban courtyards in the Netherlands," Solar Energy, vol. 103, pp. 108-124, 2014.

[6] I. Eliasson, "Urban nocturnal temperatures, street geometry and land use," Atmospheric Environment, vol. 30, no. 3, pp. 379392, 1996.

[7] T. R. Oke, Boundary Layer Climates, Methuen, London, UK, 2nd edition, 1987.

[8] H. Akbari and S. Konopacki, "Energy effects of heat-island reduction strategies in Toronto, Canada," Energy, vol. 29, no. 2, pp. 191-210, 2004.

[9] Y. Kim, H. Lee, J. Hong, and E. Son, "A study on the effect of anthropogenic heat flux and land-use on thermal environment in Pusan," Journal of Korean Society for Atmospheric Environment, vol. 16, no. 4, pp. 363-372, 2000.

[10] M. Kolokotroni, X. Ren, M. Davies, and A. Mavrogianni, "London's urban heat island: impact on current and future energy consumption in office buildings," Energy and Buildings, vol. 47, pp. 302-311, 2012.

[11] E. Lim, W. Lee, C. Choi, B. Song, and S. Jung, "An evaluation of thermal comfort on urban neighborhood park for improving thermal environment," Journal of the Korean Association of Geographic Information Studies, vol. 16, no. 4, pp. 153-170, 2013.

[12] H. Akbari, M. Pomerantz, and H. Taha, "Cool surfaces and shade trees to reduce energy use and improve air quality in urban areas," Solar Energy, vol. 70, no. 3, pp. 295-310, 2001.

[13] D. E. Bowler, L. Buyung-Ali, T. M. Knight, and A. S. Pullin, "Urban greening to cool towns and cities: a systematic review of the empirical evidence," Landscape and Urban Planning, vol. 97, no. 3, pp. 147-155, 2010.

[14] P. Cohen, O. Potchter, and A. Matzarakis, "Daily and seasonal climatic conditions of green urban open spaces in the Mediterranean climate and their impact on human comfort," Building and Environment, vol. 51, pp. 285-295, 2012.

[15] I. Eliasson, "The use of climate knowledge in urban planning," Landscape and Urban Planning, vol. 48, no. 1-2, pp. 31-44, 2000.

[16] J. N. Georgi and D. Dimitriou, "The contribution of urban green spaces to the improvement of environment in cities: case study of Chania, Greece," Building and Environment, vol. 45, no. 6, pp. 1401-1414, 2010.

[17] S. Hamada and T. Ohta, "Seasonal variations in the cooling effect of urban green areas on surrounding urban areas," Urban Forestry and Urban Greening, vol. 9, no. 1, pp. 15-24, 2010. 
[18] E. Ng, L. Chen, Y. Wang, and C. Yuan, "A study on the cooling effects of greening in a high-density city: an experience from Hong Kong," Building and Environment, vol. 47, no. 1, pp. 256271, 2012.

[19] S. Oliveira, H. Andrade, and T. Vaz, "The cooling effect of green spaces as a contribution to the mitigation of urban heat: a case study in Lisbon," Building and Environment, vol. 46, no. 11, pp. 2186-2194, 2011.

[20] M. Robitu, M. Musy, C. Inard, and D. Groleau, "Modeling the influence of vegetation and water pond on urban microclimate," Solar Energy, vol. 80, no. 4, pp. 435-447, 2006.

[21] C. Yu and W. N. Hien, “Thermal benefits of city parks," Energy and Buildings, vol. 38, no. 2, pp. 105-120, 2006

[22] S. E. Bretz and H. Akbari, "Long-term performance of highalbedo roof coatings," Energy and Buildings, vol. 25, no. 2, pp. 159-167, 1997.

[23] A. M. Coutts, E. Daly, J. Beringer, and N. J. Tapper, "Assessing practical measures to reduce urban heat: green and cool roofs," Building and Environment, vol. 70, pp. 266-276, 2013.

[24] S. S. Y. Lau and F. Yang, "Introducing healing gardens into a compact university campus: design natural space to create healthy and sustainable campuses," Landscape Research, vol. 34, no. 1, pp. 55-81, 2009.

[25] H. Li, J. Harvey, and A. Kendall, "Field measurement of albedo for different land cover materials and effects on thermal performance," Building and Environment, vol. 59, pp. 536-546, 2013.

[26] T.-P. Lin, A. Matzarakis, and R.-L. Hwang, "Shading effect on long-term outdoor thermal comfort," Building and Environment, vol. 45, no. 1, pp. 213-221, 2010.

[27] D. S. Parker and S. F. Barkaszi Jr., "Roof solar reflectance and cooling energy use: field research results from Florida," Energy and Buildings, vol. 25, no. 2, pp. 105-115, 1997.

[28] A. H. Rosenfeld, H. Akbari, S. Bretz et al., "Mitigation of urban heat islands: materials, utility programs, updates," Energy and Buildings, vol. 22, no. 3, pp. 255-265, 1995.

[29] J. R. Simpson and E. G. McPherson, "The effects of roof albedo modification on cooling loads of scale model residences in Tucson, Arizona," Energy and Buildings, vol. 25, no. 2, pp. 127137, 1997.

[30] H. Taha, "Urban climates and heat islands: albedo, evapotranspiration, and anthropogenic heat," Energy and Buildings, vol. 25, no. 2, pp. 99-103, 1997.

[31] H. Takebayashi and M. Moriyama, "Surface heat budget on green roof and high reflection roof for mitigation of urban heat island," Building and Environment, vol. 42, no. 8, pp. 2971-2979, 2007.

[32] B.-L. Wang, T. Takigawa, Y. Yamasaki, N. Sakano, D.-H. Wang, and K. Ogino, "Symptom definitions for SBS (sick building syndrome) in residential dwellings," International Journal of Hygiene and Environmental Health, vol. 211, no. 1-2, pp. 114-120, 2008.

[33] F. Yang, S. S. Y. Lau, and F. Qian, “Thermal comfort effects of urban design strategies in high-rise urban environments in a sub-tropical climate," Architectural Science Review, vol. 54, no. 4, pp. 285-304, 2011.

[34] M. Zinzi and S. Agnoli, "Cool and green roofs. An energy and comfort comparison between passive cooling and mitigation urban heat island techniques for residential buildings in the Mediterranean region," Energy and Buildings, vol. 55, pp. 66-76, 2012.
[35] H. Chen, R. Ooka, H. Huang, and T. Tsuchiya, "Study on mitigation measures for outdoor thermal environment on present urban blocks in Tokyo using coupled simulation," Building and Environment, vol. 44, no. 11, pp. 2290-2299, 2009.

[36] E. L. Krüger, F. O. Minella, and F. Rasia, "Impact of urban geometry on outdoor thermal comfort and air quality from field measurements in Curitiba, Brazil," Building and Environment, vol. 46, no. 3, pp. 621-634, 2011.

[37] A. Middel, K. Häb, A. J. Brazel, C. A. Martin, and S. Guhathakurta, "Impact of urban form and design on mid-afternoon microclimate in Phoenix Local Climate Zones," Landscape and Urban Planning, vol. 122, pp. 16-28, 2014.

[38] Korea Center for Disease Control and Prevention, "Annual report on the notified patients with heat-related illness in Korea," Public Health Weekly Report, 2013.

[39] B. G. Song and K. H. Park, "Analysis of heat island characteristics considering urban space at nighttime," Journal of the Korean Association of Geographic Information Studies, vol. 15, no. 1, pp. 133-143, 2012.

[40] B. Song and K. Park, "Validation of ASTER surface temperature data with in situ measurements to evaluate heat islands in complex urban areas," Advances in Meteorology, vol. 2014, Article ID 620410, 12 pages, 2014.

[41] Gyeongnam Green Environment Center, "Establishment of rainwater management master plan," Gyeongnam Green Environment Center Research Report, 2014.

[42] W. T. L. Chow, R. L. Pope, C. A. Martin, and A. J. Brazel, "Observing and modeling the nocturnal park cool island of an arid city: horizontal and vertical impacts," Theoretical and Applied Climatology, vol. 103, no. 1, pp. 197-211, 2011.

[43] M. Bruse and H. Fleer, "Simulating surface-plant-air interactions inside urban environments with a three dimensional numerical model," Environmental Modelling and Software, vol. 13, no. 3-4, pp. 373-384, 1998.

[44] B. G. Song, Development of environmental planning methodology for mitigation of climate change and heat island effect in urban area [Ph.D. dissertation], Changwon National University, Changwon, Republic of Korea, 2014.

[45] W. T. L. Chow, R. L. Pope, C. A. Martin, and A. J. Brazel, "Observing and modeling the nocturnal park cool island of an arid city: horizontal and vertical impacts," Theoretical and Applied Climatology, vol. 103, no. 1, pp. 197-211, 2011.

[46] W. T. L. Chow and A. J. Brazel, "Assessing xeriscaping as a sustainable heat island mitigation approach for a desert city," Building and Environment, vol. 47, no. 1, pp. 170-181, 2012.

[47] M. Samaali, D. Courault, M. Bruse, A. Olioso, and R. Occelli, "Analysis of a 3D boundary layer model at local scale: validation on soybean surface radiative measurements," Atmospheric Research, vol. 85, no. 2, pp. 183-198, 2007.

[48] A. Middel, N. Chhetri, and R. Quay, "Urban forestry and cool roofs: assessment of heat mitigation strategies in Phoenix residential neighborhoods," Urban Forestry \& Urban Greening, 2014.

[49] X. Yang, L. Zhao, M. Bruse, and Q. Meng, "Evaluation of a microclimate model for predicting the thermal behavior of different ground surfaces," Building and Environment, vol. 60, pp. 93-104, 2013.

[50] S. Park, Human-urban radiation exchange simulation model [Ph.D. thesis], University of Victoria, Victoria, Canada, 2012.

[51] H. Taha, D. Sailor, and H. Akbari, "High albedo materials for reducing cooling energy use," Tech. Rep. 31721 UC-350, Lawrence Berkeley Laboratory, 1992. 
[52] H. Akbari, S. Bretz, D. M. Kurn, and J. Hanford, "Peak power and cooling energy savings of high-albedo roofs," Energy and Buildings, vol. 25, no. 2, pp. 117-126, 1997.

[53] A. Shariah, B. Shalabi, A. Rousan, and B. Tashtoush, "Effects of absorptance of external surfaces on heating and cooling loads of residential buildings in Jordan," Energy Conversion and Management, vol. 39, no. 3-4, pp. 273-284, 1998.

[54] A. Synnefa, M. Santamouris, and H. Akbari, "Estimating the effect of using cool coatings on energy loads and thermal comfort in residential buildings in various climatic conditions," Energy and Buildings, vol. 39, no. 11, pp. 1167-1174, 2007. 

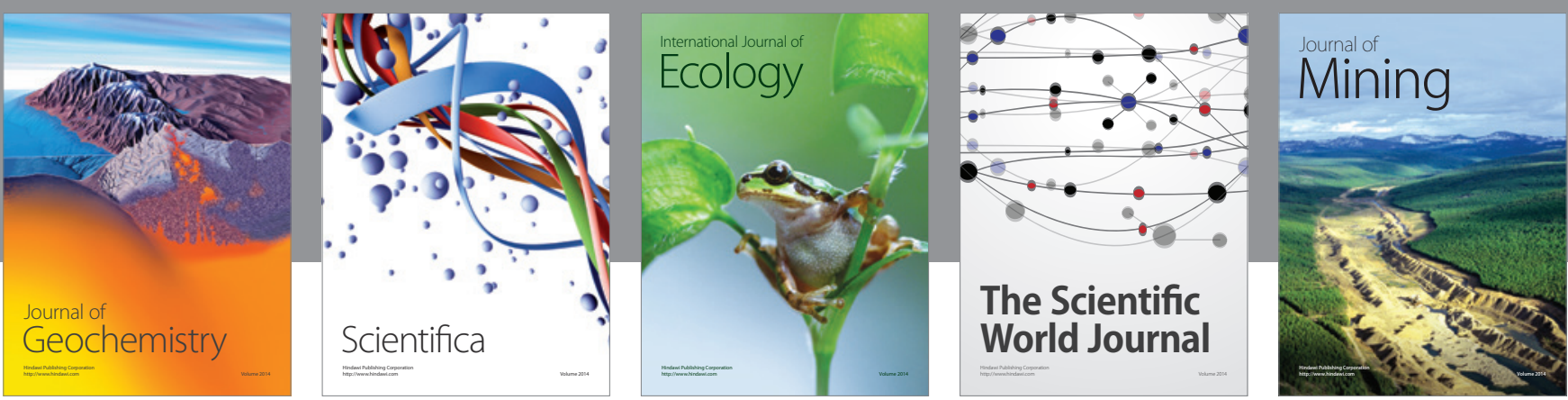

The Scientific World Journal
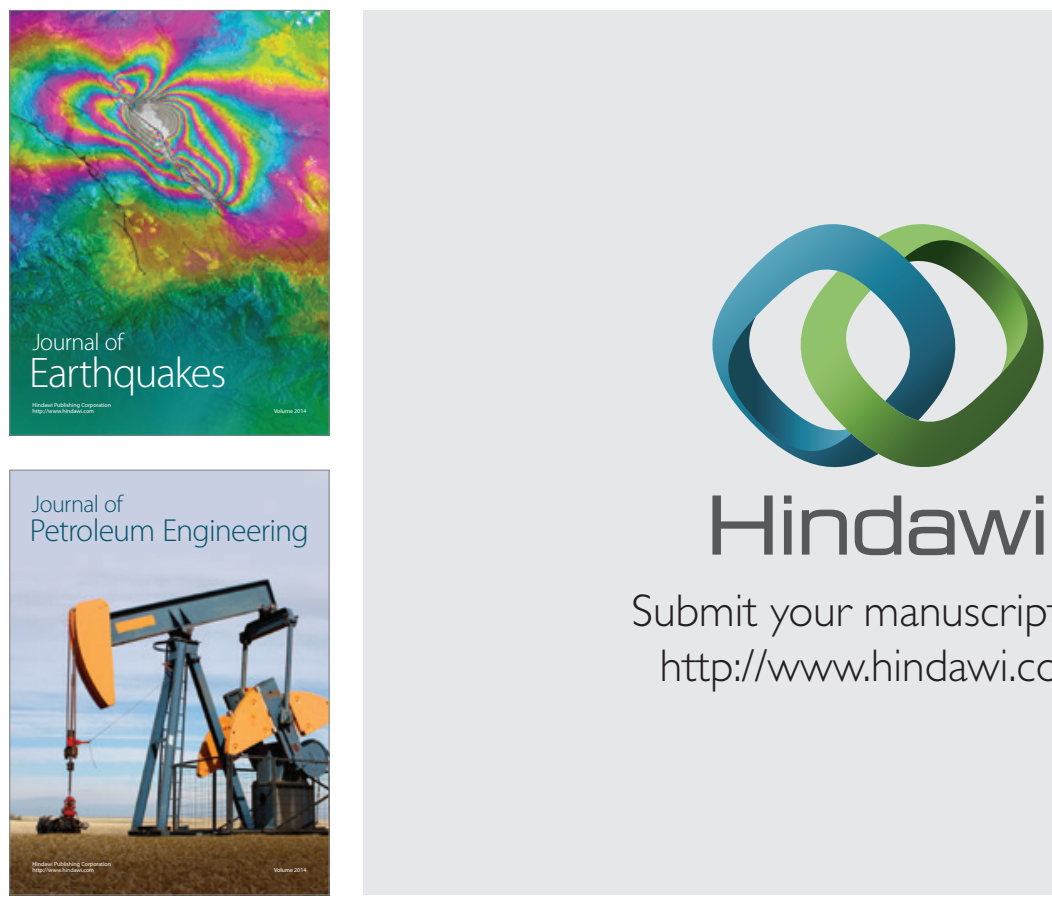

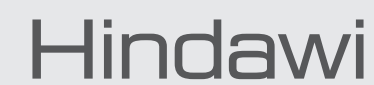

Submit your manuscripts at

http://www.hindawi.com
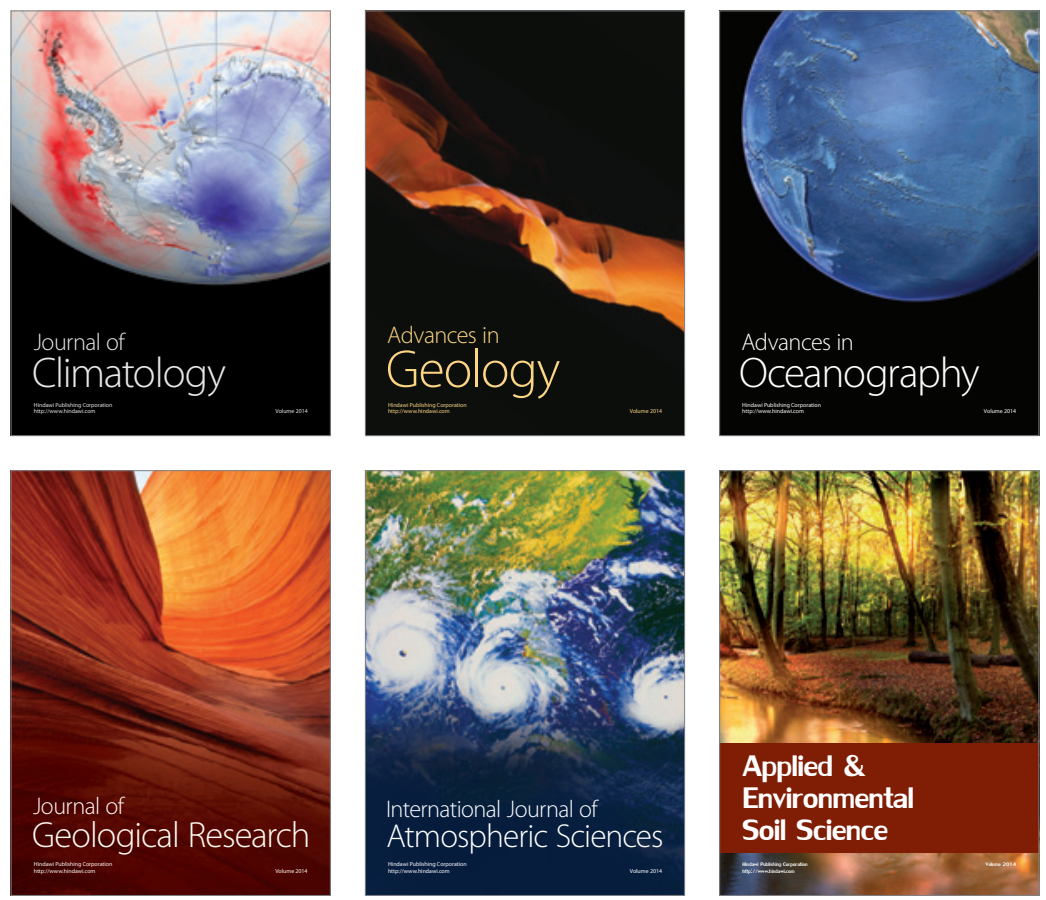
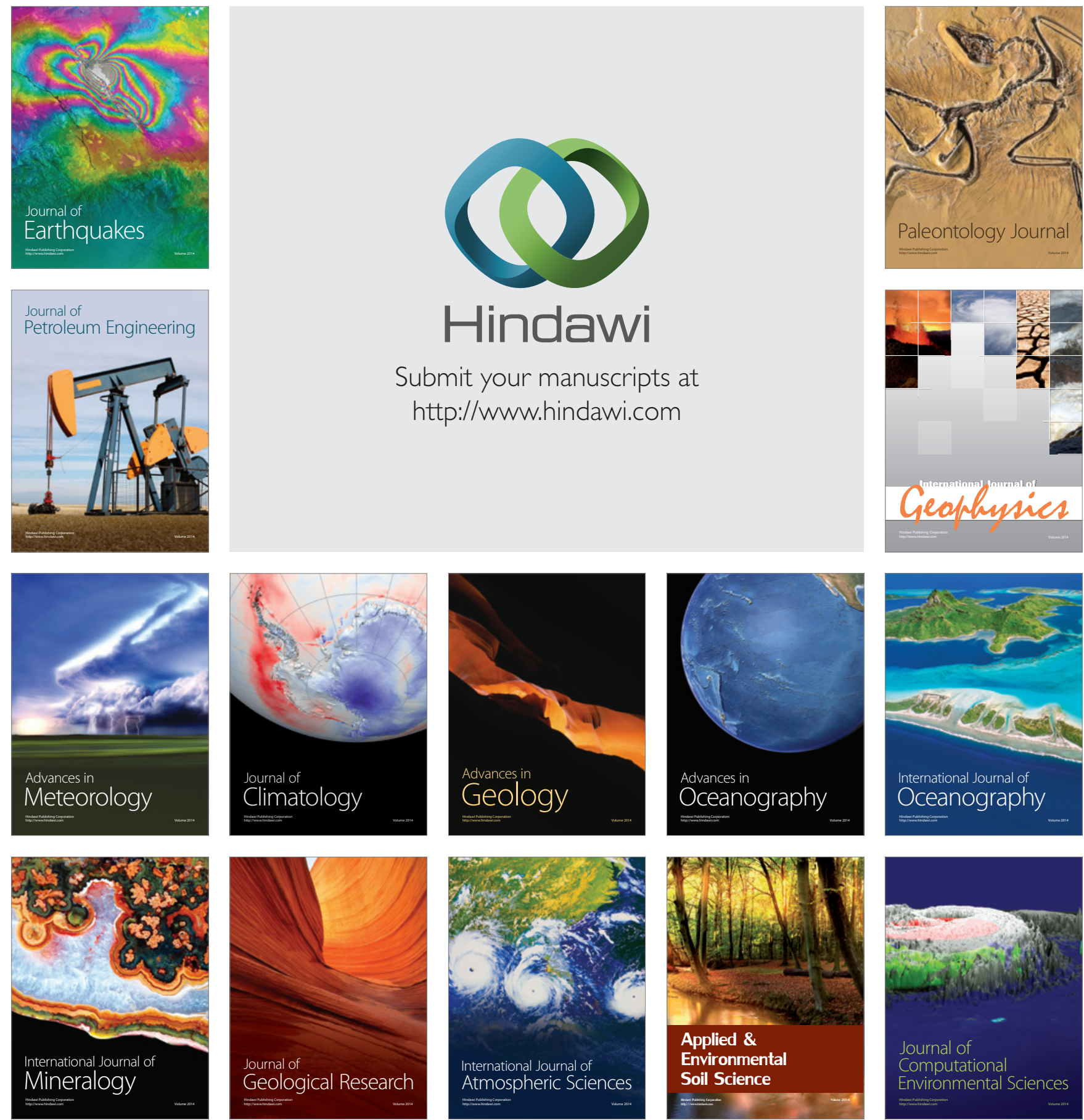